\title{
Butyrate-induced alterations of phosphoinositide metabolism, protein kinase $C$ activity and reduced CD44 variant expression in HT-29 colon cancer cells
}

\author{
R. KOPP ${ }^{1,2}$, M. FICHTER ${ }^{2}$, R. ASSERT ${ }^{3}$, A.F. PFEIFFER ${ }^{3}$ and S. CLASSEN ${ }^{2}$ \\ ${ }^{1}$ Department of Surgery, ${ }^{2}$ GSF-Research Institute, Klinikum Grosshadern, University of Munich and \\ ${ }^{3}$ Medical Clinic IV, Charite, Campus Benjamin Franklin, University of Berlin and Institute for \\ Nutritional Research, Potsdam-Rehbrïcke, Berlin-Potsdam, Germany
}

Received September 15, 2008; Accepted November 24, 2008

DOI: 10.3892/ijmm_00000175

\begin{abstract}
Initiation of cell growth and neoplastic transformation frequently involves activation of growth factor receptor-coupled tyrosine kinases and stimulation of the phosphoinositide second messenger system. Altered expression of CD44 variants was reported in several malignant tumor types with possible implications for tumor progression and prognosis. CD44 variant expression was reported to be associated with second messenger activation and differentiation. We therefore investigated the effects of butyrateinduced short-term differentiation on phosphoinositide signaling, phospholipase $\mathrm{C}$ and protein kinase $\mathrm{C}$ activity and alteration of CD44 variant expression in human HT-29 colon carcinoma cells. HT-29 cells were cultured with sodium butyrate for 6 days. Phosphoinositide turnover was measured by $\left.{ }^{32} \mathrm{P}\right]$ orthophosphate incorporation and phospholipase $\mathrm{C}$ activity by determination of the release of $\left[{ }^{3} \mathrm{H}\right]$ inositolphosphates from $\left[{ }^{3} \mathrm{H}\right]$ myoinositol prelabeled cells. Protein kinase $\mathrm{C}$ activity was determined by histone III-S phosphorylation, PKC subtype expression by RNase protection analysis, and CD44 variant expression was determined by
\end{abstract}

Correspondence to: Dr Reinhard Kopp, Department of Surgery, Klinikum Grosshadern, University of Munich, Marchioninistr. 15, D-81377 Munich, Germany

E-mail: rkopp@med.uni-muenchen.de

Abbreviations: HDAC, histone deacetylase; PA, phosphatidic acid; PI, phosphatidylinositol; PIP, phosphatidylinositol-4phosphate; $\mathrm{PIP}_{2}$, phosphatidylinositol-4,5-bisphosphate; PLC, phospholipase C; PKC, protein kinase C; PI-3 kinase, phosphatidylinositol 3-kinase; HBSS, Hanks balanced salt solution; DMEM, Dulbecco's modified Eagle's medium; HEPES, N-(2-hydroxyethyl)piperazine-N'2-ethanesulfonic acid; TPA, tetradecanylphorbol acetate; STAT1, signal transducers and activators of transcription 1

Key words: HT-29 cells, intestinal differentiation, sodium butyrate, phosphoinositide metabolism, protein kinase C, CD44 variants, enterocytic differentiation
RT-PCR using variant-specific primers. Treatment of HT-29 human colon carcinoma cells with sodium butyrate caused a dose-dependent inhibition of cell proliferation $\left(\mathrm{IC}_{50}, 2.5 \mathrm{mM}\right)$ with morphologic signs of an enterocytic differentiation following 6 days of treatment. The phosphoinositide turnover as determined by ${ }^{32} \mathrm{P}$-incorporation under non-equilibrium conditions showed a $30-40 \%$ inhibition of labeled phosphoinositides and phosphatidic acid and a dose-dependent inhibition of cholinergically stimulated phospholipase $\mathrm{C}$ activity as a secondary event following butyrate-induced enterocytic differentiation. However, long-term incubation of HT-29 cells with phorbol ester or an inhibitor of classical and novel PKC subtypes did not affect cell proliferation. In butyrate-treated HT-29 cells activation of calcium-dependent protein kinase $\mathrm{C}$ by cholinergic stimulation or phorbolester treatment induced an increase in membrane-bound cPKC activity, while expression of distinct high- molecular CD44 variant transcripts v3 (670 bp), v5 (940 bp) and v8 (535 bp) were drastically reduced after butyrate pretreatment. Enterocytic differentiation of HT-29 colon carcinoma cells seems to be associated with alterations in phosphoinositide resynthesis, phospholipase $\mathrm{C}$ activity and ligand/receptorinduced PKC translocation. The observed reduction of distinct high-molecular CD44v3, v5 and v8 variants following butyrate-induced differentiation indicates an association of specific CD44 variant expression with the malignant phenotype of HT-29 colon cancer cells, thus being possible targets for new diagnostic and therapeutic strategies.

\section{Introduction}

Regulation of cell proliferation in normal and malignant intestinal epithelial cells are mediated by several signaling pathways (1). Binding of growth factors like EGF, TGF $\alpha$, IGF-I or insulin to specific receptors leads to an activation of tyrosine-specific protein kinases, an intrinsic property of this receptor family. Other growth factors such as PDGF, bombesin or thrombin additionally mediate their mitogenic signals by activating the phosphoinositide system, resulting in a specific receptor-coupled hydrolysis of the membrane phospholipid phosphatidylinositol-4,5,-bisphosphate $\left(\mathrm{PIP}_{2}\right)$ with an increase in the metabolically active second messengers 
inositoltrisphosphate $\left(\mathrm{IP}_{3}\right)$, diacylglycerol $(\mathrm{DAG})$ and activation of PI3-kinase (PI-3K) $(2,3)$. Evidence for the involvement of a permanent activated phosphoinositide metabolism in malignant transformation was supported by in vitro experiments of Faletto et al (4), demonstrating a decrease in phosphoinositide turnover in DMSO (dimethylsulfoxide)-differentiated Friend erythroleukemia cells, preceeding a reduction in c-myc proto-oncogene expression. Simlarly, other authors showed an increase in phosphoinositide turnover or phosphoinositide-derived second messengers after transfection of fibroblasts with oncogene products, like the ras-oncogene, viral oncogenes or the SV 40 virus $(5,6)$. Activation of protein kinase $\mathrm{C}$ by phorbol esters and elevation of intracellular calcium levels by calcium ionophores have been shown to be mitogenically active cofactors during the initiation of DNA synthesis $(7,8)$. We and others have shown reduced levels of PKC activity as determined by cPKC-mediated substrate phosphorylation assays in colonic adenomas and carcinomas (9-11). These findings indicated that an increased phosphoinositide metabolism, probably leading to an increased or downregulated protein kinase $\mathrm{C}$ activity, may contribute to the development of colonic malignancies.

Overexpression of the adhesion molecule CD44 and its splice variants was reported to be involved in tumor progression, metastatic disease and poor prognosis in different malignant diseases, including colorectal cancer (12). Expression of CD44 variants was reported to be regulated by growth factors, intracellular kinases and cytokines $(12,13)$. In SH-NK cells, CD44 variant expression was regulated by growth factors and activation of protein kinase $\mathrm{C}$ and PI-3K (14). Barshishat et al recently reported the inhibition of CD44 variant expression in butyrate-treated HM7 colon carcinoma cells (16). However, the possible effects of butyrate-induced differentiation on intracellular phosphoinositide signaling, PKC activities and CD44 variant expression have so far not been investigated in detail in human intestinal epithelial cells.

To investigate changes in intracellular phosphoinositide signaling and CD44 variant expression in malignant and differentiated colonic epithelial cells, we used HT-29 colon carcinoma cells, described to show phenomena of enterocytic differentiation after treatment with sodium butyrate (16). Sodium butyrate, a short chain fatty acid is an inhibitor of histone deacetylase (HDAC) leading to hyperacetylation of histones with modulation of chromatin structure and intracellular transcriptional activity (17). In vivo, sodium butyrate is generated by colonic fermentation of dietary fibre and starch (18). The intestinal presence of sodium butyrate is considered to be chemopreventive against the development of colonic neoplasias, although recent clinical trials failed to support the protective effect of a fibre-rich diet in humans (18-21).

In the present study, we therefore investigated possible alterations of phosphoinositide metabolism, muscarinic $\mathrm{M}_{3}$ receptor-stimulated phospholipase C activity, total PKC activity, $\mathrm{PKC}$ subtype expression and CD44 variant expression in either untreated HT-29 cells or after incubation with sodium butyrate. Finally, we discuss the possible implications of described oncogene mutations or defective suppressor gene expression regarding the responsiveness of transformed intestinal epithelial cells to butyrate.

\section{Materials and methods}

Drugs and radiochemicals. All reagents were of analytical grade and purchased from Merck, Darmstadt, Germany unless indicated otherwise. DMEM, HBSS and fetal calf serum (FCS) were from Gibco, Karlsruhe, Germany. PMSF (phenylmethylsulfonylfluoride) and HEPES were from Serva, Heidelberg, Germany. DEAE 52 (diethylaminoethyl cellulose) and Watman P1 phosphocellulose paper were from Whatman, Maidstone, Kent, UK. $\left[\gamma^{32} \mathrm{P}\right] \mathrm{ATP},\left[{ }^{3} \mathrm{H}\right]$ myoinositol, $\left[{ }^{32} \mathrm{P}\right]-$ orthophosphate, $\left[{ }^{3} \mathrm{H}\right]$ thymidine and $\left[{ }^{3} \mathrm{H}\right]$ arginine were from Amersham Buchler, Braunschweig, Germany. Histone III-S, diacylglycerol and phosphatidylserine were from Sigma, Taufkirchen, Germany. Nonidet P-40 was from LKB, Bromma, Sweden. GF 109203X (bisindolylmaleimide) was from Calbiochem, Merck Eurolab KGaA, Darmstadt, Germany.

Cell culture. Cells were obtained from the American Type Culture Collection (ATCC, Rockville, MD), subcultured with $0.05 \%$ trypsin/ $1 \mathrm{mM}$ EDTA in DMEM, containing $6 \%$ FCS, $1 \mathrm{mM}$ pyruvic acid, $2 \mathrm{mM}$ glutamine, $100 \mathrm{U} / \mathrm{ml}$ penicillin, $50 \mathrm{U} / \mathrm{ml}$ streptomycin and $200 \mathrm{IU} / \mathrm{ml}$ nystatin in $75-\mathrm{cm}^{2}$ disposable tissue culture flasks in a humified atmosphere of $5 \% \mathrm{CO}_{2} / 95 \%$ air. For the experiments, cells were seeded at a density of $2 \times 10^{5}$ cells in 24 -well flat bottom tissue culture plates (Falcon, Heidelberg, Germany) and grown until subconfluency $\left(0.7-1.0 \times 10^{6} \mathrm{cells} /\right.$ well). For analysis of cell growth, viable cells were counted using the trypan blue exclusion method.

Analysis of carcinoembryonic antigen release. Levels of carcinoembryonic antigen were reported to increase in HT-29 cells during butyrate-induced enterocytic differentiation. Therefore, the amount of carcinoembryonic antigen released into the culture medium was determined in untreated and butyrate-treated cells using an automated ELISA, as described by Lamerz (22).

Analysis of phospholipid turnover. For the investigation of phospholipid turnover, cells were cultured in phosphate-free HBSS (containing $1 \mathrm{mM}$ pyruvic acid, $2 \mathrm{mM}$ glutamin, HEPES $20 \mathrm{mM}, \mathrm{NaHCO}_{3} 3.7 \mathrm{~g} / \mathrm{l}$ ) for $60 \mathrm{~min}$ prior to the experiment and then incubated in $\mathrm{HBSS}\left(\mathrm{PO}_{4}\right.$-free) with [ $\left.{ }^{32} \mathrm{P}\right]-$ orthophosphate $(10 \mu \mathrm{Ci} / \mathrm{ml})$ and indicated substances at $36.5^{\circ} \mathrm{C}$ for up to $60 \mathrm{~min}$ in a shaking water bath. Incubations were terminated by aspirating the incubation medium. Cells were then washed twice with cold HBSS, and cold methanol was added. Cells were scraped off in plastic tubes, and phospholipids were extracted according to the method of Bligh and Dyer, as described previously (23). Separation of lipids was performed by thin-layer chromatography after pretreatment of silica gel plates (Merck DC 60) with 50\% ethanol, $1 \%$ potassiumoxalat and $2 \mathrm{mM}$ EDTA. Phospholipids were stained with iodine vapour, exposed to autoradiography film (Amersham Hyperfilm) for $48-76 \mathrm{~h}$ at $-80^{\circ} \mathrm{C}$ and identified by co-migration with commercial phospholipid standards.

Determination of inositolphosphates. For measurements of inositolphosphate release, cells were preincubated with 
$\left[{ }^{3} \mathrm{H}\right]$ myoinositol $(2 \mu \mathrm{Ci} / \mathrm{ml})$ for $48 \mathrm{~h}$ until complete isotopic equilibrium was achieved. Accumulation of inositolphosphates was measured in the presence of $\mathrm{LiCl}_{2}(10 \mathrm{mM})$, known to inhibit the degradation of inositolmonophosphates, and cells were then stimulated for $30 \mathrm{~min}$. Phospholipase C activity, as represented by inositolphosphate release, was determined after elution with $15 \mathrm{ml} 1 \mathrm{M}$ ammonium formate/ $0.1 \mathrm{M}$ formic acid (23), and radioactivity was measured in the first $4 \mathrm{ml}$ of each eluate by liquid scintillation spectrophotometry (Beckmann LS 7000).

Assay for PKC activity. Calcium-dependent classical PKC activity in cytosol and membrane preparations was assayed by the incorporation of ${ }^{32} \mathrm{P}$ into histone III-S (9). Cytosolic PKC activity was separated by centrifugation and then applied to DEAE-Sephacel (DE 52, Whatman, $100 \mu 1$ packed volume) in Eppendorf tubes after equilibration of DEAE-cellulose with $20 \mathrm{mM}$ Tris-HCl, $1 \mathrm{mM}$ EDTA and $0.1 \%$ mercaptoethanol. The membrane pellet was homogenized with Nonidet P-40 (1\%) in buffer A at $4^{\circ} \mathrm{C}$, sonicated, centrifuged at $12,000 \mathrm{x} \mathrm{g}$ and applied to tubes with DEAE-cellulose. Protein kinase $\mathrm{C}$ activity was assayed by the addition of $10 \mu \mathrm{l}$ DEAE-eluate to a final volume of $40 \mu 1$ (containing $1.25 \mathrm{mg} /$ $\mathrm{ml}$ histone III-S, $12.5 \mathrm{mM} \mathrm{MgCl} 2,20 \mathrm{mM}$ Tris- $\mathrm{HCl}, 0.1 \mathrm{mM}$ $\left.\mathrm{CaCl}_{2}, \mathrm{pH} 7.5\right)$ and $65 \mu \mathrm{M}\left[\gamma^{-32} \mathrm{P}\right] \mathrm{ATP}(200-400 \mathrm{cpm} / \mathrm{pmol})$, and samples were incubated for $5 \mathrm{~min}$ at $30^{\circ} \mathrm{C}$. The assays were terminated by spotting $30 \mu 1$ of the reaction mix on Whatman P-81 phosphocellulose paper, and the filters were immediately soaked in ice-cold trichloroacetic acid (20\%). Unbound radioactivity was reduced by extensive washes in perchloric acid, $\mathrm{H}_{2} \mathrm{O}$ and acetone. $\mathrm{PS} / \mathrm{DAG} / \mathrm{Ca}^{2+}$-dependent histone III-S phosphorylation was performed in the presence of $10 \mu \mathrm{g} / \mathrm{ml}$ phosphatidylserine (PS), $1.0 \mu \mathrm{g} / \mathrm{ml} \mathrm{sn-1,2-}$ diacylglcerol (DAG) and $0.1 \mathrm{mM}$ calcium. The amount of ${ }^{32} \mathrm{P}-$ incorporation into histone in the absence of PS/DAG/Ca ${ }^{2+}$ and in the presence of eluted enzyme and EGTA $(1.25 \mathrm{mM})$ was subtracted. PKC activity was expressed as the percentage of total PKC activity found either in the cytosolic or membrane-associated fraction.

Analysis of PKC subtype expression. Analysis of protein kinase $\mathrm{C}$ subtype expression was performed as previously described by Assert et al (24). Briefly, PKC $\alpha$ fragments were generated by reverse transcription with MMLV reverse transcriptase (Gibco, Eggenstein, Germany) of $1 \mu \mathrm{g}$ RNA of HT-29 cells. For in vitro transcription, plasmids containing isotype-specific probes for PKC $\alpha, \delta$ or G3PDH were linearized with $B g l \mathrm{I}$ and $\mathrm{Xba \textrm {I }}$, respectively. PKC subtype fragments were transcribed with T7 RNA polymerase (Boehringer, Mannheim, Germany) with a specific activity of $2000 \mathrm{Ci} / \mathrm{mmol}$. For RNase protection analysis, $20 \mu \mathrm{g}$ of total cellular RNA was hybridized with PKC subtype transcripts $(300,000 \mathrm{cpm})$. After submerse denaturation for $10 \mathrm{~min}$ at $85^{\circ} \mathrm{C}$ and cooling overnight to $54^{\circ} \mathrm{C}$, RNase digestion was performed with $1000 \mathrm{U} /$ $\mathrm{ml}$ RNase T1 (Boehringer). RNase digestion was terminated with proteinase $\mathrm{K}$ and phenol chloroform extraction. After phenol precipitation, washing and denaturing probes were run on a $6 \%$ denaturing polyacrylamide gel, and autoradiography was performed for 1-2 days using MP-hyperfilm (Amersham, Buchler). For quantification of PKC subtypes, mRNA autoradiograms were scanned by laser densitometry relative to G3PDH (glycerol-3-phosphate dehydrogenase) expression.

Analysis of CD44 variant expression. RNA from HT-29 colon cancer cells was purified by guanidium-thiocyanate-phenol extraction followed by isopropanol precipitation. Cells were lysed directly with RNAzol B reagent (Tel-Test), and cellular protein and DNA were extracted with $1 / 10$ vol chloroform and centrifugation at $10.000 \mathrm{x}$ g. RNA was precipitated with $1 \mathrm{vol}$ 2-propanol and centrifuged at $10.000 \mathrm{x}$ g. RNA pellets were washed once in $70 \%$ ethanol, air dried and resuspended in an appropriate volume of $\mathrm{H}_{2} \mathrm{O}$ at $65^{\circ} \mathrm{C}$. Total cellular RNA was used as template for the synthesis of first-strand cDNA with random-primed oligonucleotide hexamers. The cDNA products were then used as templates for PCR. Amplifications were carried out with an initial cycle $\left(2 \mathrm{~min}\right.$ at $94^{\circ} \mathrm{C}, 1 \mathrm{~min}$ at $55^{\circ} \mathrm{C}$ and $2 \mathrm{~min}$ at $72^{\circ} \mathrm{C}$ ) followed by 30 cycles each of $45 \mathrm{sec}$ at $94^{\circ} \mathrm{C}, 1 \mathrm{~min}$ at $55^{\circ} \mathrm{C}$ and $1 \mathrm{~min}$ at $72^{\circ} \mathrm{C}$ using a Biometra Uno Thermocycler (Biometra, Göttingen, Germany). The oligonucleotide primer pair $\mathrm{C} 2 \mathrm{~A}$ and $\mathrm{C} 13$ hybridizes to the constant region of CD44 flanking the alternatively spliced exons. Primers specific to eight of the alternatively spliced exons (variant primers: pv3I, pv4, pv5, pv6, pv7, pv8, pv9, pv10; primers for flanking conserved regions C13, C2A) were used for amplification of CD44 variants, as described by Fichter et al (15) and van Weering et al (25). PCR reactions were performed under mineral oil in a total volume of $50 \mu 1$. To check for RNA and cDNA quality, a portion of the constitutively expressed housekeeping gene GAPDH (glyceraldehyde-phosphate dehydrogenase) was amplified along with the probes. PCR products were separated on $1.4 \%$ agarose gels, stained with ethidium bromide and photographed with a video camera (Cybertech).

Flow cytometry. Fluorescence of cells stained with monoclonal antibodies against CD444v6 epitopes (Bender Med Systems) was measured with the FACScan flow cytometer (Becton Dickinson). Data were analysed with the Lysis II program (Becton Dickinson). Adherent HT-29 cells were removed from the culture plates with cold PBS plus $1 \mathrm{mM}$ EDTA. The cells were incubated with a primary anti-CD44 antibody, diluted 1:20 PBS + 10 FCS, for 1 at $4^{\circ} \mathrm{C}$ and then stained with a fluorescein-labeled secondary antibody (Mouse IGG/ Dako), diluted 1:50, for $45 \mathrm{~min}$. The secondary antibody was taken as negative control, defining background fluorescence. Fluorescence above background was defined as positive CD44 variant fluorescence. Prior to measurement, the cells were stained with propidium iodide $(0.2 \mu \mathrm{g} / \mathrm{ml})$ to identify viable cells, and only viable cells were gated and further analyzed.

Data analysis. Data are reported as the means \pm SE from indicated numbers of experiments each performed in duplicate or triplicate. Statistical analysis was performed by the Student's t-test for paired and by the Mann-Whitney U-test for unpaired samples.

\section{Results}

Effects of butyrate on cell morphology, differentiated functions and proliferation in HT-29 cells. Treatment of HT-29 human 


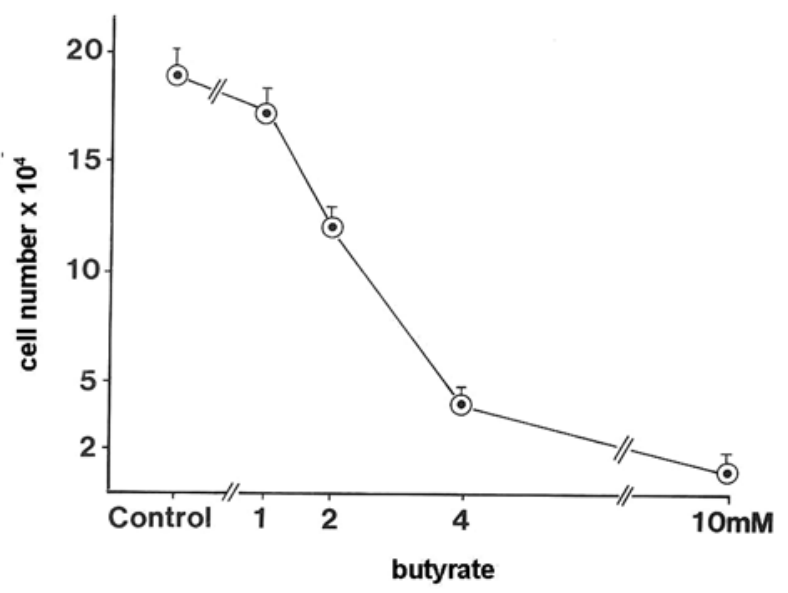

Figure 1. Growth inhibition of HT-29 cells after incubation with indicated concentrations of sodium butyrate $(0-10 \mathrm{mM})$ for 6 days. Viable cells were counted following staining using the trypan blue exclusion method.

colon carcinoma cells with sodium butyrate caused a dosedependent inhibition of cell proliferation with an $\mathrm{IC}_{50}$ of $2.5 \mathrm{mM}$ after 6 days of incubation (Fig. 1). Inhibition of proliferation by butyrate was associated with morphologic signs of an enterocytic differentiation in this cell line (Fig. 2A and B). Treatment of HT-29 cells with sodium butyrate ( $2 \mathrm{mM})$ showed several typical mucin-filled vacuoles with an increase in apoptotic tumor cells floating in the culture medium, a 5- to 7-fold increase in alkaline phosphatase activity (data not shown) and an increased release in carcinoembryonic antigen into the culture medium ( $12.1 \mathrm{vs} 33.4 \mathrm{ng} / \mathrm{ml} / 24 \mathrm{~h} / 10^{6}$ cells in untreated and butyrate-treated cells; $\mathrm{p}<0.05)$. Butyrate treatment of HT-29 cells was associated with a significant and dose-dependent reduction in DNA and protein synthesis as determined by $\left[{ }^{3} \mathrm{H}\right]$ thymidine or $\left[{ }^{3} \mathrm{H}\right]$ arginine incorporation (data not shown).

Phosphoinositide metabolism, phospholipase $C$ activity and protein kinase $C$ translocation after butyrate treatment. Effects of butyrate-induced differentiation on phosphoinositide metabolism were measured by $\left.{ }^{[32} \mathrm{P}\right]$ orthophosphate incorporation into phospholipids of untreated (not shown) and cholinergically stimulated HT-29 cells. In untreated cells carbachol time-dependently increased the incorporation of $\left.{ }^{[32} \mathrm{P}_{\mathrm{i}}\right]$ into phosphatidic acid (PA) (1.5-fold), phosphatidylinositol (PI) (4.3-fold) and polyphosphoinositides (PIP and $\mathrm{PIP}_{2}$ ) (2-fold). In butyrate-treated HT-29 cells (2 mM for 6 days), [ $\left.{ }^{32} \mathrm{P}\right]$ orthophosphate incorporation showed a $30-40 \%$ reduction in labeled phosphoinositides and phosphatidic acid under non-equilibrium conditions for 1-30 min (Fig. 3). This effect of butyrate on phosphoinositide resynthesis was observed after a butyrate treatment of $48 \mathrm{~h}$, indicating that effects on phosphoinositide metabolism were secondary following reduction of DNA and protein synthesis and induction of differentiation or apoptosis.

To investigate a possible impact of sodium butyrate on $\mathrm{Gq} /$ receptor-coupled phospholipase $\mathrm{C}$ activity, we investigated the release of $\left[{ }^{3} \mathrm{H}\right]$ inositolphosphates induced by receptormediated cleavage of prelabeled $\left[{ }^{3} \mathrm{H}\right]$ phosphoinositides after
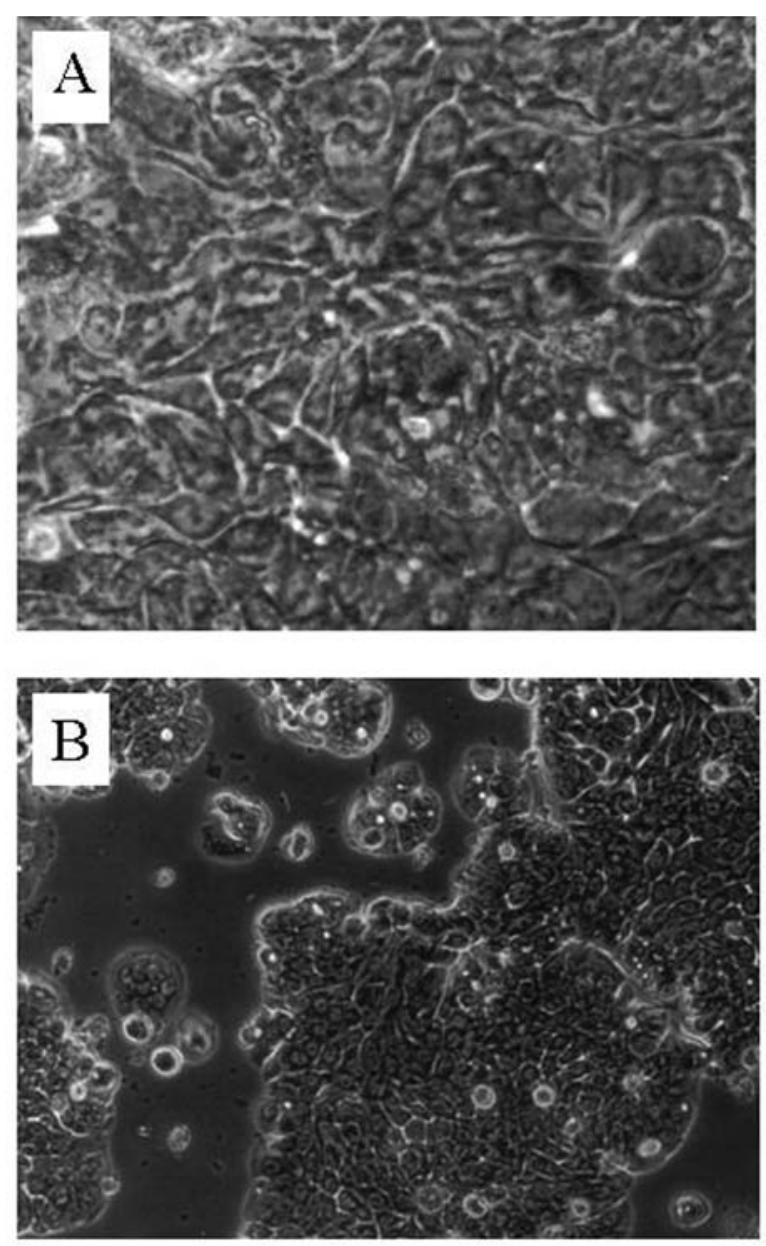

Figure 2. Cultured HT-29 cells without (A, magnification x100) or after treatment with sodium butyrate $(2 \mathrm{mM})$ for 6 days (B, magnification $\mathrm{x} 40)$.

stimulation with carbachol $(1 \mathrm{mM})$ in the presence of lithium chloride $(10 \mathrm{mM})$. Muscarinic $\mathrm{M}_{3}$ receptor stimulation increased the release of water soluble $\left[{ }^{3} \mathrm{H}\right]$ inositolphosphates between 2.0- and 9.5-fold with a significant inhibition of stimulated phospholipase $\mathrm{C}$ activity after incubation with increasing concentrations of sodium butyrate $(0,1,2$ and $4 \mathrm{mM})$ for 6 days (Fig. 4). For analysis of stimulated inositolphosphate release, results were corrected for different cell numbers and the amount of incorporated radioactivity in separated phosphoinositides following butyrate treatment. Quantitative analysis of separated phospholipids indicated no difference in the phospholipid levels of untreated or butyratetreated HT-29 cells (data not shown).

Alterations of PKC activity or differential expression of various PKC subtypes were found to be involved in regulation of intestinal cell growth and malignant transformation. To investigate a possible involement of PKC subtypes during enterocytic differentiation, we analyzed the activity of protein kinase C after sodium butyrate treatment in HT-29 cells. Protein kinase $\mathrm{C}$ activity was determined as total activity or cytosolic or membrane-bound activity by histone-III-S phosphorylation in the presence of phosphatidylserin, diacylglycerol and calcium. As shown in Table I, membraneassociated cPKC activity was not altered in unstimulated HT-29 

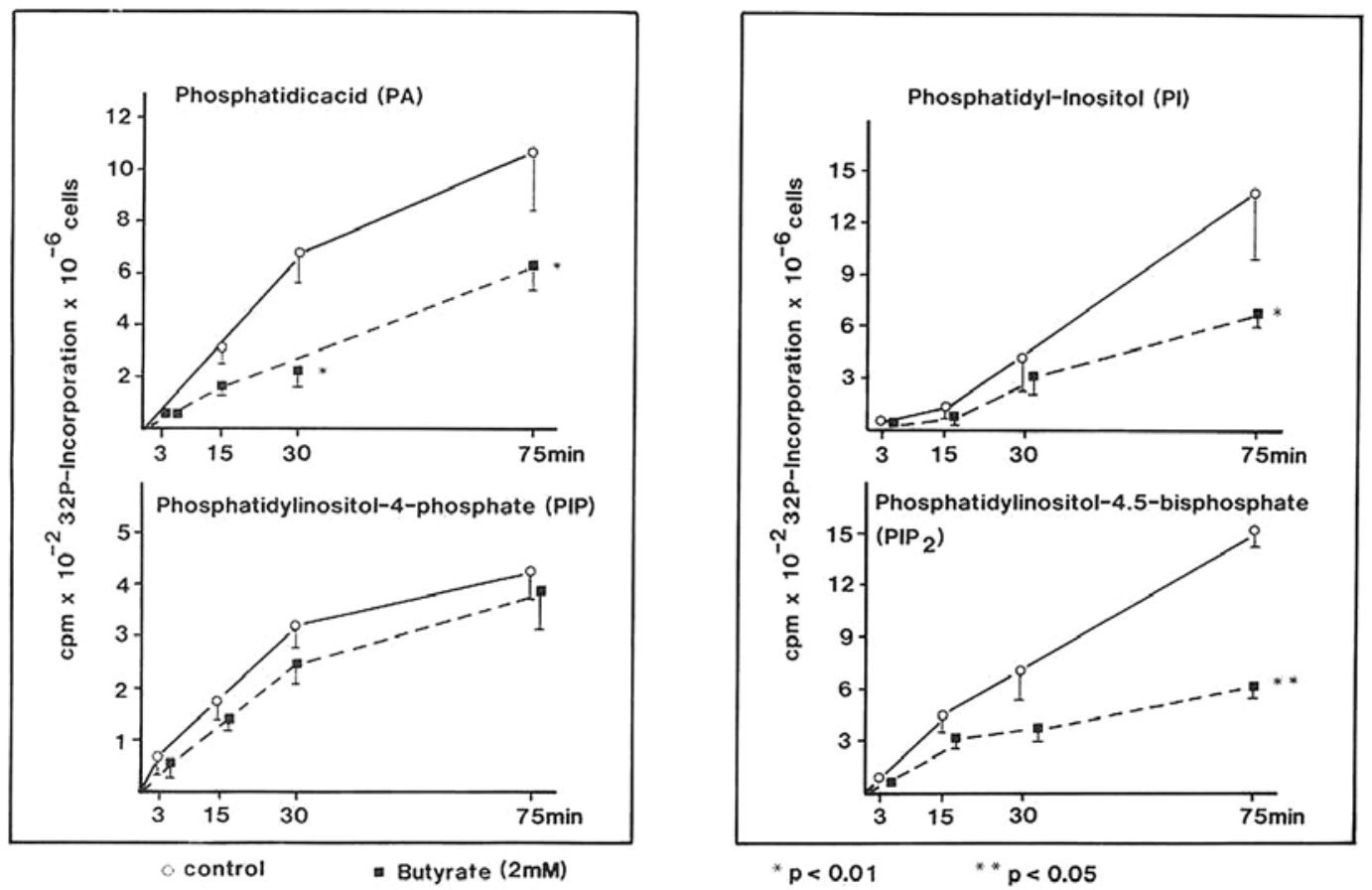

Figure 3. Basal phosphoinositide metabolism of HT-29 cells after treatment with sodium butyrate (2 mM) for 6 days. Analysis of phosphoinositide metabolism [(phosphatidylinositol (PI), PIP, $\mathrm{PIP}_{2}$ and phosphatidic acid (PA)] by incorporation of [ $\left.{ }^{32} \mathrm{P}\right]$ orthophosphate for indicated time points followed by phospholipid extraction and separation using thin-layer-chromatography and determination of incorporated radioactivity. Data shown represent mean values \pm SE of five independent experiments each performed in triplicate. ${ }^{*} \mathrm{p}<0.05$ and $\left.{ }^{* *} \mathrm{p}<0.01\right)$.

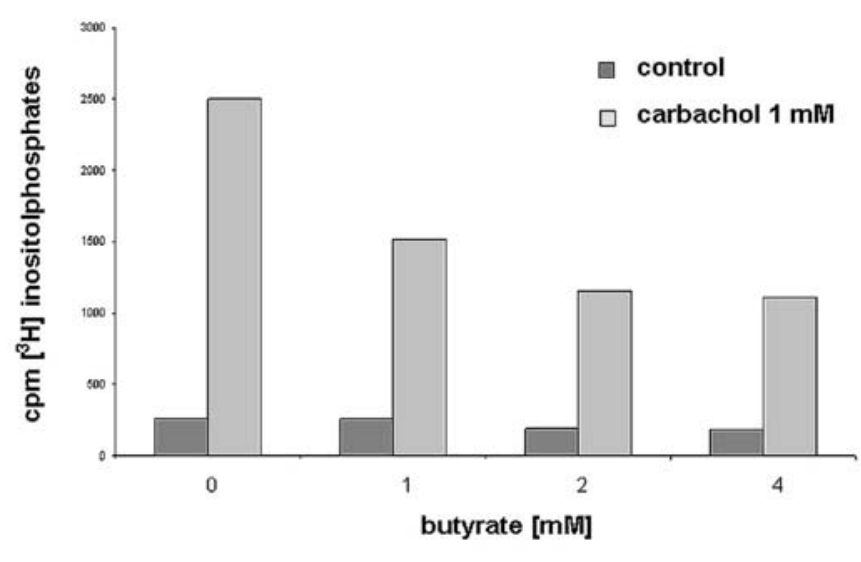

Figure 4. Analysis of phospholipase C activity in butyrate-treated HT-29 cells. To investigate the effects of butyrate-induced differentiation of basal and carbachol-stimulated phospholipase $\mathrm{C}$ activity, release of water-soluble $\left[{ }^{3} \mathrm{H}\right]$ inositolphosphates was measured in HT-29 cells preincubated with increasing concentrations of butyrate for 6 days. $\left[{ }^{3} \mathrm{H}\right]$ inositolphosphates and prelabelled phospholipids were separated by anion exchange chromatography. Data show mean values determined in three independent experiments. $\left[{ }^{3} \mathrm{H}\right]$ inositophosphate accumulation in the presence of $\mathrm{LiCl}_{2}(10 \mathrm{mM})$ varied in untreated cells (dark grey columns) between $100-260 \mathrm{cpm} / 10^{5}$ cells and in carbachol-stimulated cells (light grey columns) between 733 and $2550 \mathrm{cpm} /$ $10^{5}$ cells. Carbachol-stimulated IP release was significantly reduced in butyrate-treated cells in comparison to untreated cells ( $\mathrm{p}<0.05$ with $1 \mathrm{mM}$ butyrate and $\mathrm{p}<0.01$ with 2 and $4 \mathrm{mM}$ butyrate).

cells following butyrate treatment, but stimulated membranebound and translocated cPKC activity was increased following incubation with carbachol or phorbol ester in butyrate-treated cells $(\mathrm{p}<0.05)$. Incubation of HT-29 cells with higher
Table I. Basal, carbachol- and phorbol ester-stimulated protein kinase $\mathrm{C}$ activity in HT-29 cells without and after treatment with sodium butyrate $(2 \mathrm{mM})$ for 6 days. ${ }^{\mathrm{a}}$

\begin{tabular}{llcc}
\hline & \multicolumn{2}{c}{$\begin{array}{c}\text { Percentage of membrane-associated } \\
\text { cPKC activity }\end{array}$} \\
\cline { 2 - 4 } & None & $\begin{array}{c}\text { Carbachol } \\
(1 \mathrm{mM})\end{array}$ & $\begin{array}{c}\text { TPA } \\
(1 \mathrm{nM})\end{array}$ \\
\hline Untreated cells & $21 \%$ & $36 \%$ & $66 \%-$ \\
$\begin{array}{l}\text { Butyrate-treated cells } \\
2 \mathrm{mM}\end{array}$ & & & $66 \%$ \\
$4 \mathrm{mM}$ & $22 \%$ & $44 \%$ & $87 \%$ \\
\hline
\end{tabular}

aProtein kinase $\mathrm{C}$ activity was determined by [ $\left.{ }^{32} \mathrm{P}\right]$ phosphorylation of histone-III-S in the presence of phosphatidylserine, diacylglycerol and calcium. Cells were incubated with sodium butyrate $(2 \mathrm{mM})$ for 6 days and then stimulated with the indicated substances for $15 \mathrm{~min}$. Total $\mathrm{PKC}$ activity varied between 8.2 and $12.4 \mathrm{pmol} / \mathrm{min} / \mathrm{mg}$ protein. ${ }^{*} \mathrm{p}<0.05$ and ${ }^{* *}<0.01$ in comparison to untreated cells. n.d., not determined.

concentrations of butyrate $(4 \mathrm{mM})$ further increased carbacholstimulated membrane-bound PKC activity to 75. Butyrate did not directly affect PKC or interfere with cofactors such as calcium, diacylglycerol or phospholipid to stimulate PKC activity (data not shown). These findings seem to indicate an upregulation of cPKC subtype-mediated receptor/G proteinsignaling during enterocytic differentiation in HT-29 cells, with probable restoration of $\mathrm{PKC}$-mediated feedback 


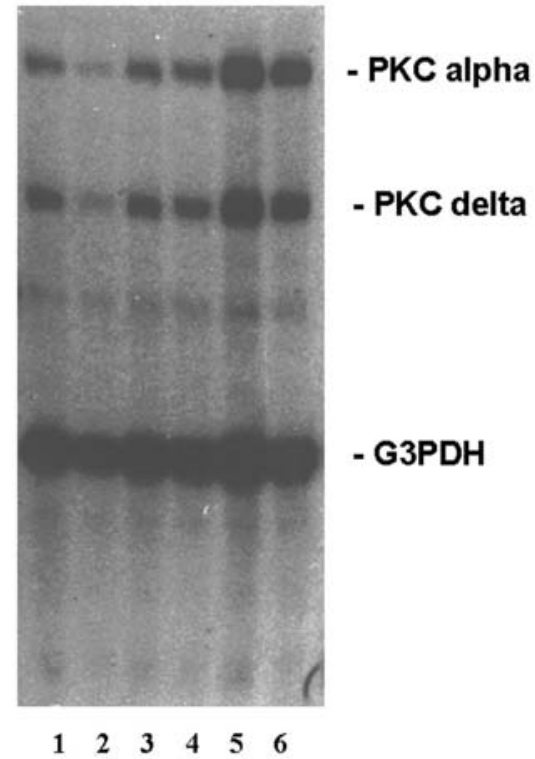

Figure 5. Determination of CD44 variant expression by RNase protection analysis. HT-29 cells incubated with or without butyrate for 6 days were analyzed for PKC $\alpha$ and $\mathrm{PKC} \delta$ expression by RNase protection analysis. Expression of PKC subtype expression was quantified relative to G3PDH expression. Lanes 1-3 show untreated HT-29 cells and lanes 4-6 show cells following butyrate treatment $(2 \mathrm{mM})$ for 6 days.

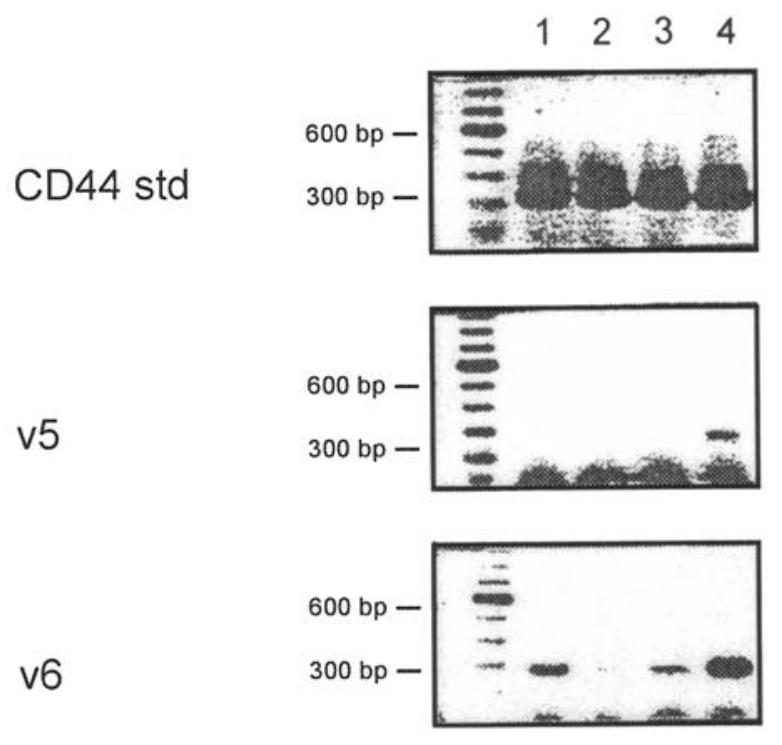

Figure 6. Analysis of CD44 standard (std), CD44 v5-C and v6-C variant expression in HT-29 cells in either unstimulated cells (lane 1), after treatment with an inhibitor of protein kinase C (lane 2, GF 109203X), growth factor stimulation (lane 3, insulin-like growth factor I) or phorbol ester $(1 \mathrm{nM})$ for $6 \mathrm{~h}$ (lane 4$)$.

inhibition of ligand and receptor-activated phosphoinositide signaling.

Protein kinase $C \alpha$ and $\delta$ expression in butyrate-treated HT-29 cells. Phorbol ester-induced PKC activation was shown to cause inhibition of proliferation in association with an upregulation of $\mathrm{PKC} \delta$ and downregulation of $\mathrm{PKC} \alpha$ expression in other cell types. We therefore investigated $\mathrm{PKC} \alpha$
Table II. Description of CD44 variant compositions detected in HT-29 colon carcinoma cells.

\begin{tabular}{llcc}
\hline PCR primer & Exon composition & $\begin{array}{c}\text { Calculated } \\
\text { size (bp) }\end{array}$ & $\begin{array}{c}\text { Observed } \\
\text { size (bp) }\end{array}$ \\
\hline C13/C2A & C-C & 320 & 324 \\
& C-v8-v9-v10-C & 710 & 720 \\
& C-V6-v8-v9-v10-C & 970 & 981 \\
pv3I/C2A & v3-C & 320 & 320 \\
& v3-v8-v9-v10-C & 680 & 673 \\
pv5/C2A & v5-C & 320 & 320 \\
& v5-v6-v7-v8-C & 730 & 721 \\
& v5-v8-v9-v10-C & 800 & 796 \\
pv6/C2A & v6-v7-v8-C & 520 & 514 \\
& v6-v7-v8-v9-C & 610 & 604 \\
& v6-v7-v8-v9-v10-C & 820 & 808 \\
pv8/C2A & v8-v9-C2A & 330 & 337 \\
& v8-v9-v10-C2A & 535 & 541 \\
\hline
\end{tabular}

and $\delta$ mRNA expression in butyrate-treated HT-29 cells. As shown in Fig. 5, we did not observe relevant and sustained changes of PKC $\alpha$ or $\delta$ mRNA expression in HT-29 cells after treatment with $2 \mathrm{mM}$ butyrate for 6 days. In addition, incubation of HT-29 cells with either phorbol esters (PMA) or a known inhibitor of PKC activity (GF 109203X) did not show any effect on proliferation of HT-29 cells during 6 days of treatment (data not shown). These results suggest that butyrate induced differentiation and inhibition of proliferation is independent of classical and novel PKC subtype activity in HT-29 cells.

Regulation of CD44 variant expression by protein kinase $C$. In HT-29 cells, stimulation of protein kinase $C$ by activating phorbol esters (TPA) or growth factors (IGF-I, PDGF) showed a marked increase in CD44s, v5-C and v6-C variant expression (Fig. 6). Phorbol ester-stimulated protein expression of CD44v6 variants were completely abolished after additional incubation with the PKC inhibitor GF 109203X, as analyzed by flow cytometry (data not shown), indicating that CD44 variant expression in HT-29 cells is regulated at least in part by classical or novel protein kinase $\mathrm{C}$ subtypes.

Reduced expression of distinct CD44 variants in butyratetreated HT-29 cells. Since CD44 variant expression was reported to be associated with malignant transformation, tumor cell migration and invasion, we analyzed CD44 variant expression in butyrate-treated HT-29 cells. Incubation of HT-29 cells with sodium butyrate ( $2 \mathrm{mM}$ for 6 days) showed specific alterations of CD44 variant expression probably related to the malignant phenotype of this colon cancer cell line. A description of the various CD44 variant compositions detected in HT-29 colon carcinoma cells is shown in Table II. In butyrate-treated HT-29 cells C13/C2A PCR products showed a shift from strong expression of the CD44 epithelial form (710 bp, C-v8-v9-v10) and a distinctly expressed 320-bp 

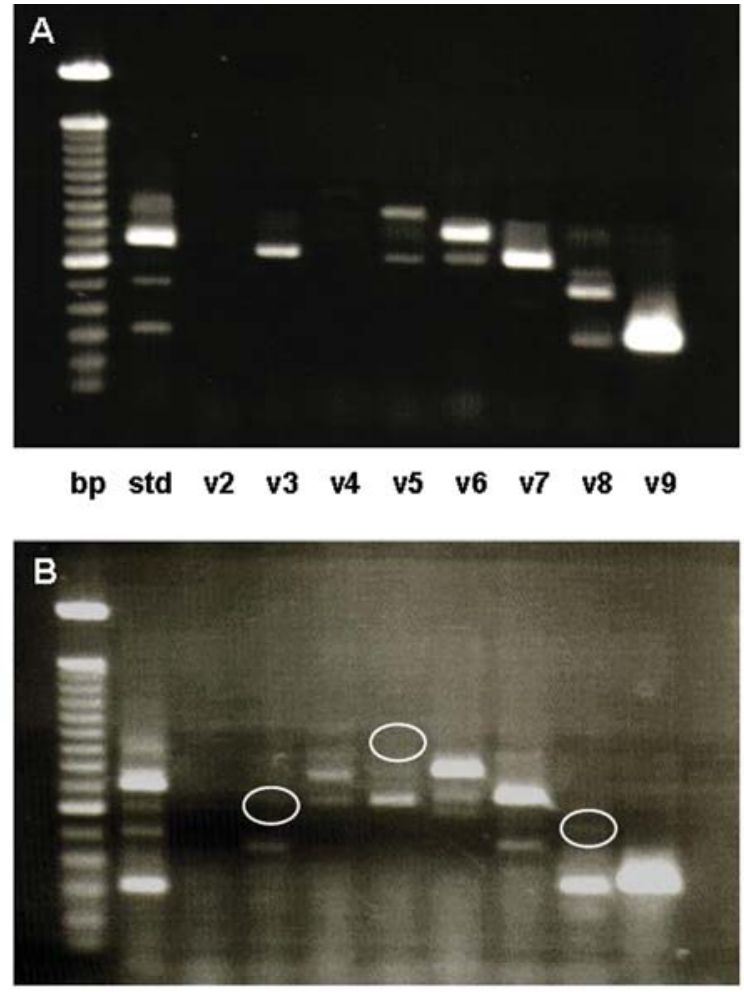

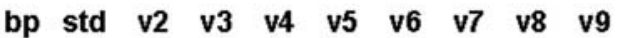

Figure 7. CD44 variant expression in untreated HT-29 cells (A) or after incubation with butyrate for 6 days. Most prominent alterations and deleted transcripts of CD44 variants following butyrate treatment are marked by white circles (B).

band (C-C, standard form) in untreated cells to an equal and stronger expression of the 320-bp standard form in butyratetreated cells (Fig. 7). RT-PCR analysis of CD44 variant using specific CD44 variant primers showed a tumor-specific CD44 variant expression in untreated HT-29 cells with a specific expression of the CD44v3,v8-10 corresponding to a strong amplification of a $680-b p$ v3 PCR product. In butyratetreated HT-29 cells, expression of this pv3I/C2A PCR product (680 bp, v3,v8-10 variant) was almost completely reduced. Expression of high-molecular splice variants of the pv5/C2A (940 bp, v5-10) and pv8/C2A (535 bp, v8-v10-C) PCR products was reduced with a shift to a more pronounced expression of smaller CD44 variant molecules pv5/C2A (650 bp, v5-v8) and pv8/C2A (330 bp, v8-v9-C) in butyratetreated cells. Remarkably, CD44v6 variant expression corresponding to a dominant PCR product of $820 \mathrm{bp}$ (v6-v10) and two weakly detectable transcripts $(610 \mathrm{bp}$, v6-v9-C and $520 \mathrm{bp}$, v6-v8) were not changed following butyrate-induced differentiation in HT-29 cells. These findings suggest a tumorspecific expression pattern of CD44 variants in colon carcinoma cells being important candidates for targeted diagnostic and therapeutic strategies.

\section{Discussion}

Changes in second messenger signaling have been implicated with malignant transformation and regulation of growth and tumor progression in various cancer cells, including colorectal cancer. Adhesion molecules play an important role mediating interactions between the tumor cell and the peritumoral microenvironment. The transmembrane glycoprotein CD44 and its splice variants have been implicated in cell adhesion, proliferation, migration, tumor cell invasion and metastatic disease (12). The regulation of CD44 variant expression seems to involve specific splicing factors, RAS/MAPK signaling and intracellular kinases including protein kinase $\mathrm{C}$ and c-Jun N-terminal kinase (JNK) $(26,27)$. We previously showed that the expression of CD44 variant isoforms is regulated by phosphoinositide 3-kinase and protein kinase $\mathrm{C}$ in SK-N-SH human neuroblastoma cells (15). In intestinal epithelial cells, sodium butyrate, a potent HDAC inhibitor, was shown to be involved in the regulation of proliferation and differentiation potently preventing malignant cell transformation. Butyrate was reported to mediate its effects on intestinal epithelial cell control by an interaction with nuclear protein expression, intracellular kinase activities and cell cycle regulators (28). However, possible effects of butyrate treatment on intracellular phosphoinositide signaling in association with a detailed analysis of CD44 variant expression has not yet been investigated in human colon carcinoma cells.

Therefore, the aim of this study was to investigate possible changes in intracellular phosphoinositide signaling, basal or stimulated phospholipase $\mathrm{C}$ or protein kinase $\mathrm{C}$ activity and CD44 variant expression in HT-29 human colon carcinoma cells in association with butyrate-induced enterocytic differentiation. Our data indicate that butyrate-induced differentiation of HT-29 cells is associated with a secondary decrease in phosphoinositide synthesis and reduced ligand/ receptor-activated phospholipase $\mathrm{C}$ activity, an increased protein kinase $\mathrm{C}$ translocation induced by cholinergic ligand/ $\mathrm{M}_{3}$ receptor activation and specific repression of presumably tumor cell-related CD44 variants. Inhibition of proliferation and reduced CD44 variant expression following butyrate treatment was not associated with changes in total PKC activity or PKC $\alpha$ or PKC $\delta$ subtype expression in HT-29 cells. Based on these findings, differentiation and growth regulation of HT-29 cells seems to be independent of classical and novel PKC activity. Butyrate seems to restore downregulated PKC responsiveness following receptor stimulation and to inhibit CD44 variant expression supposed to be involved in intestinal tumor cell proliferation, migration and invasion.

These effects seem to occur as a secondary event following induction of enterocytic differentiation because butyrate did not directly inhibit phosphokinase activity or phospholipase C-induced hydrolysis of prelabeled polyphosphoinositides. In addition, we observed, in butyrate-treated HT-29 cells, an early and dose-dependent inhibition of DNA and protein synthesis. Germann et al showed, in CC531 rat colon carcinoma cells treated with butyrate, an inhibition of cyclin D1, cyclin E and Fos-like antigen 1 (Fosl1), c-myc and follistatin, indicating a potent inhibition of downstream signaling induced via activation of the wnt/ß-catenin pathway (29). Similar to our conclusion, butyrate had no effect on mRNA levels of phosphoinositide kinase expression. In human intestinal cells, butyrate was additionally associated with an inactivation of ERK kinase activity during differentiation (30), and inhibition of proliferation of human colon cancer cell lines by butyrate resulted in an inhibition of ERK $1 / 2$ activity (31), demonstrating that mitogen-activated protein kinases 
(MAPKs) play a pivotal role in intestinal growth and differentiation. In three other human colon carcinoma cell lines butyrate was shown to potently inhibit proliferation and activities of c-Src and focal adhesion kinase associated with reduced in vitro invasiveness (32).

Receptors activating phosphoinositide signaling via GTPbinding protein coupled to phospholipase $\mathrm{C}$ are known to stimulate proliferation and various physiologic cellular functions. Colonic epithelial cells are physiologically exposed to activators of cholinergic receptors and protein kinase $\mathrm{C}$, such as secondary bile acids, reported to activate muscarinic receptors and transactivate epidermal growth factor signaling $(33,34)$. We first described muscarinic $\mathrm{M}_{3}$ receptors on HT-29 human colon carcinoma cells coupled to phosphoinositide breakdown and second messenger signaling, and others have shown the role of $\mathrm{M}_{3}$ receptors mediating proliferative responses induced by bile acids $(35,36)$. The observed increase in receptor-activated PKC translocation following butyrate treatment of HT-29 cells might indicate that butyrate is able to restore negative feedback control of presumably downregulated PKC activity thereby controling receptor activated phosphoinositide signaling by inhibition of receptor/G-protein interactions. This described upregulation of $\mathrm{M}_{3}$ receptoractivated calcium-dependent protein kinase $\mathrm{C}$ might be explained by earlier reports describing an upregulation of ganglioside GM3 synthesis following butyrate treatment in colon cancer cells, representing an important cofactor for PKC translocation. Specifically, GM3 ganglioside is involved in the regulation of EGF receptor signaling requiring protein kinase $\mathrm{C} \alpha$ translocation with the formation of a specific regulatory complex involving ganglioside GM3, tetraspanin CD82 and caveolin-1 mediating suppression of EGFR signaling by PKC $\alpha$-mediated EGFR Thr ${ }^{654}$ phosphorylation (37). Therefore, upregulation of receptor-stimulated calciumdependent cPKC activity, most likely involving $\mathrm{PKC} \alpha$, might have effects on regulation of autocrine growth of HT-29 colon carcinoma cells, known to possess EGF receptors, secrete EGFR ligands and respond to $\mathrm{M}_{3}$ receptor-induced transactivation of EGF receptor signaling.

Interaction of butyrate with intracellular protein kinase $\mathrm{C}$ activity and the various described PKC subtypes might be another explanation for the observed effects of butyrate on intracellular signaling. We and others have previously reported altered PKC activities in colonic malignancies, although the precise role of PKC and its subtypes has not yet been elucidated (9-11). Protein kinase $C$ was originally described as a phospholipid and calcium-dependent protein kinase involved in various cellular functions including regulation of growth and malignant transformation in various cancer cells. The subsequent identification and classification into three groups of, to date, eleven PKC subtypes is based on structural and activational characteristics. The classical or conventional cPKCs (PKC $\alpha, \mathrm{PKC} ß \mathrm{I}, \mathrm{PKC} ß \mathrm{II}, \mathrm{PKC} \gamma)$ are activated by phosphatidylserine, diacylglycerol and calcium, novel PKCs (PKCo, PKC $8, \mathrm{PKC} \varepsilon, \mathrm{PKC} \eta, \mathrm{PKC} \theta$ ) are calcium independent and activated by DAG and PS and atypical aPKC's (PKC $\zeta \mathrm{PKC} \lambda$ ) are calcium independent and do not require DAG, while PS can regulate their activity $(38,39)$. In addition, involvement of protein kinase $\mathrm{C} \delta$ subtype following butyrate treatment was shown in $\mathrm{AA} / \mathrm{C} 1$ human adenoma cells causing a dose-dependent stimulation of caspase- 3 activity, protein kinase $\mathrm{C} \delta$ expression and inhibition of $\mathrm{p} 38$ MEK signaling leading to apoptotic cell death (40). However, the role of protein kinase $\mathrm{C}$ activity and the contribution of its various subtypes to malignant transformation, growth regulation and tumor progression is not yet completely understood.

Activation of PKC was reported to induce differentiation in various cell types $(41,42)$. Overexpression of PKCßII in colonic epithelium seems to results in hyperproliferation and an increased susceptibility to carcinogenesis with an early increase in carcinogenesis, whereas PKC was downregulated in colonic tumors $(43,44)$. Data from Orchel et al $(45)$ have shown that differentiation of Caco- 2 cells by butyrate treatment is dependent on PKC and c-Jun N-terminal kinase (JNK) activity. In LIM1215 and CaCo-2 colon carcinoma cells, butyrate reduced total protein kinase $\mathrm{C}$ (PKC) activity and specifically reduced the expression of PKC $\alpha$ and $\mathrm{PKC} \varepsilon$ subtypes, an effect that was reproduced by incubations with a specific inhibitor of histone deacetylase (46). In our experiments with HT-29 cells, long-term stimulation or inhibition of PKC did not affect proliferation (data not shown), and in butyrate-treated cells, mRNA expression of PKC $\alpha$ and $\delta$ subtypes was not different following 6 days of incubation. Also, total PKC activity was unchanged after butyrateinduced differentiation in HT-29 cells, although carbacholstimulated translocation was dose-dependently increased after butyrate treatment. The lack of long-term effects of butyrate on PKC $\delta$ mRNA expression in HT-29 cells is of interest, because others have shown potent upregulation of $\mathrm{PKC} \delta$ expression following butyrate treatment within $2 \mathrm{~h}$ of treatment, although long-term effects of butyrate on PKC $\delta$ subtype expression have not been investigated $(40,47)$. Therefore, we cannot exclude butyrate-induced effects downstream of early PKC $\delta$ expression. Previously, we described, in T84 human intestinal cells, a potent upregulation of PKC $\delta$ following prolonged phorbol ester treatment paralleled by a decrease in PKC $\alpha$ expression in association with potent inhibition of cell proliferation (24). Based on these reports and our findings, we conclude that PKC subtypes seem to differentially regulate cell proliferation and differentiation in intestinal epithelial cells and that prolonged PKC upregulation of classical or novel PKC subtypes do not seem to be involved in butyrate-induced growth inhibition and differentiation in HT-29 cells.

CD44 is a transmembrane glycoprotein involved in the interaction between cells and the extracellular matrix with implications for cell migration, malignant transformation and the metastatic potential of tumor cells. Butyrate treatment was shown to reduce CD44 variant expression and especially CD44v6 variant expression in HM7 cells (16). Notably, in our study, butyrate treatment did not markedly change the CD44v6 composition in HT-29 cells, indicating that the responsiveness of CD44 variant expression might be differentially regulated in different colon carcinoma cells. These findings support conflicting data reported so far investigating the possible prognostic impact of CD44v6 protein expression as determined by immunohistochemistry in patients with colorectal cancer $(48,49)$. Also in our patients with colorectal cancer analyzed for CD44v6 variant 
immunoreactivity we did not find a prognostic relevance of CD44v6 immunoreactivity. However, Peng et al recently showed a prognostic impact of CD44v6 immunoreactivity in a subgroup of rectal cancer patients following tumor resection and total mesorectal excision (50).

In our study, RT-PCR analysis of CD44 variants in untreated HT-29 cells using CD44 variant-specific primers showed a cell type-related CD44 variant expression with a distinct expression of CD44v3,v8-10, CD44v5-10 and CD44v8-10 transcripts. In contrast, in butyrate-treated HT-29 cells, the expression of the CD44v3,v8-10 variant was almost completely reduced and a shift to a more pronounced expression of smaller CD44 v5 and v8 variants was observed. We additionally investigated samples of human colonic adenomas and carcinomas in comparison to normal adjacent mucosa and found a similar expression and upregulation of specific neoplasia-associated CD44 variant compositions (unpublished data). In HM7 human colon carcinoma cells, butyrate caused a general inhibition of CD44 variant expression especially of the epithelial form (v8-v10) and the CD44v6 variant (16). However, in contrast to these and our results, in CC531 rat colon carcinoma cells, butyrate did not affect the expression of CD44 transcripts, while aspirin transiently reduced CD44 expression after $2 \mathrm{~h}$ of incubation (40). Therefore, these findings indicate a differential and probable tumor cell-related regulation of CD44 variant expression following butyrate treatment in different colon carcinoma cells.

The described inhibitory effects of butyrate on CD44 variant expression can be explained by earlier studies demonstrating a cis-regulatory epidermal growth factor (EGF) regulatory element (ERE) involved in the regulation of EGFinduced CD44 gene transcription in human neuroblastoma cells $(51,52)$. In HM7 colon cancer cells, Barshishat et al (16) showed that butyrate downregulates CD44v6 variant transcription by binding of yet unknown nuclear proteins to the described ERE motif present in the CD44 promoter region. These findings strongly suggest a direct nuclear regulatory mechanism mediating butyrate-induced alterations of CD44 variant expression with phenotypic reduction of the tumor metastatic potential of these colon carcinoma cells.

In addition to the reported involvement of CD44 variants in colorectal carcinogenesis and cancer prognosis, other reports have indicated another important role of CD44 variants for prediction of antitumor response and as a target for new anticancer therapies. According to data from Bates et al (53), CD44 variant expression seems to be involved in the induction of chemoresistance via activation of Lyn kinase and phosphoinositide 4-kinase/Akt pathways. New therapeutic strategies targeting CD44 variant expression using CD44 antisense cDNA or transfection and intratumoral application of constructs producing silencing (si)RNA against the transmembrane region of CD44 exons were reported to show reduced tumor growth and tumor volume in colon carcinoma xenograft model systems $(54,55)$.

However, development of colon cancer is still one of the major causes of cancer-related death in humans, even in the presence of the multiple anticarcinogenic and pro-apoptotic effects of relevant intraluminal concentrations of butyrate. Therefore, other tumor biologic mechanisms will finally determine the progression of an early transformed intestinal cell to either undergo differentiation, apoptosis or to progress to invasive and metastatic cancer. Human HT-29 human colorectal adenocarcinoma cells host truncating mutations in APC (adenomatous polyposis coli) alleles, wild-type ras, active mutant B-raf, wild-type raf-1 and mutant p53 (56). Acetylation of the C-terminal domain of wild-type p53 seems to be required for induction of p53-dependent apoptosis induced by butyrate, and tumor cells harboring mutated p53 might therefore be unresponsive to this pathway. Tumor cells with mutated p53 show reduced responsiveness to butyratemediated upregulation of PKC $\delta$ and p21waf1/p53-induced apoptosis in HCT116 cells overexpressing PKCS (57). These results have shown, that $\mathrm{p} 21^{\text {wafl/cip } 1}$ and $\mathrm{p} 53 \mathrm{wt}$ are downstream effectors of protein kinase $\mathrm{C} \delta$ required for butyratemediated induction of apoptosis and tumor suppression. Therefore, induction of p53-dependent apoptosis by butyrate requires activation of $\mathrm{PKC} \delta, \mathrm{p} 53$ wild-type and p21 expression. As shown in our study, butyrate did not induce overexpression of PKC $\delta$ in HT-29 cells, and others have shown that overexpression of PKC $\delta$ in HT-29 cells was ineffective for induction of apoptosis in p53 mutant HT-29 cells (58). However, even tumor cells with wild-type p53 can be unresponsive to DNA damage due to reduced expression of downstream p53-related target molecules such as p53AIP1, protein kinase C $\delta$, STAT1 and p21 $1^{\text {waf1/cip1 } 1}$ (59). In addition, other $\mathrm{p} 53$-independent pathways have been described following mediating butyrate effects supporting the role of an intact mitochondrial membrane potential being involved in initiation and maintenance of butyrate-mediated p53independent $\mathrm{p} 21^{\text {waf1/cip } 1}$ induction of $\mathrm{G}_{0} / \mathrm{G}_{1}$ growth arrest and apoptosis (60).

HT-29 colon carcinoma cells additionally contain mutated B-Raf, a serine/threonine kinase observed in colorectal carcinomas. B-Raf activating mutations and hypermethylation of SLC5A8, were shown to be important events for the development of sessile serrated adenomas. Importantly, intracellular butyrate might contribute to the genesis of serrated neoplasias of the colon by histone hyperacetylation and transcriptional activation of specific genes in addition to decreased $\mathrm{p} 21^{\mathrm{WAF} 1 / \mathrm{CIP} 1}$ expression and activation of the MAPK pathway $(61,62)$.

Finally, HCT116 colon cancer cells, which harbor an activating k-ras mutation, respond to butyrate with increased apoptosis, in comparison to the same cell type in which the mutant k-ras allele was deleted. (63). Based on these results, activation of ras during transformation of colonic epithelial cell with subsequent downregulation of STAT1 and reduced p21 transcription is able to sensitize cells to apoptosis by HDAC inhibitors. Recently, Choudhary and Wang (64) confirmed the reactivity of oncogenic H-ras mutations for histone deacetylase inhibitors to induce apoptosis in H-ras (V12)-transformed HT-29 cells, indicating that oncogenic ras mutations possess a novel pro-apoptotic ability in addition to the known tumorigenic potential. In addition, a positive feedback loop was described in which non-mutant ras signaling promotes CD44v6 splicing, and CD44v6 then sustains late ras signaling in HeLa cells (65). Therefore, these reported data indicate that a critical accumulation of mutations, loss of suppressor functions or sustained cell 
activation will finally define the unresponsiveness of transformed intestinal cells to the potent antiproliferative and differentiating effects of butyrate.

In summary, we describe butyrate-associated alterations in intracellular phosphoinositide signaling, protein kinase $\mathrm{C}$ activity and CD44 variant compositions in HT-29 cells used as a model for enterocytic differentiation of human intestinal cells. The observed tumor cell-related expression pattern of CD44 variants with marked repression of distinct CD44 variants following butyrate treatment may suggest novel concepts for tumor-specific diagnostic assays or therapeutic strategies targeting these CD44 variants. However, the critical accumulation of oncogenic mutations or defects in suppressor functions will enable selected transformed intestinal cells to escape from differentiating and pro-apoptotic effects mediated by intraluminal concentrations of butyrate.

\section{Acknowlegements}

Part of this work was carried out by Marion Fichter during her postgraduate studies to fulfill the requirements for her doctoral thesis. The authors wish to thank R. Lamerz for determining the carcinoembryonic antigen levels and E. Doischer for the excellent technical assistance.

\section{References}

1. Fearnhead NS, Wilding JL and Bodmer WF: Genetics of colorectal cancer: hereditary aspects and overview of colorectal carcinogenesis. Br Med Bull 64: 27-43, 2002.

2. Rozengurt E, Guha S and Sinnett-Smith J: Gastrointestinal peptide signalling in health and disease. Eur J Surg Suppl 587: $23-38,2002$

3. Rozengurt E: Mitogenic signalling pathways induced by $G$ protein-coupled receptors. J Cell Physiol 213: 589-602, 2007.

4. Faletto DL. Arrow AS and MacaraI G: An early decrease in phosphatidylinositol turnover occurs on induction of Friend cell differentiation and precedes the decrease in c-myc expression. Cell 43: 315-325, 1985

5. Macara IG: Oncogenes, ions and phospholipids. Am J Physiol 248: C3-C11, 1985.

6. Kaplan DR, Witmann M, Schaffhausen B, Pallas DC, White M, Cantley I and Roberts TM: Common elements in growth factor stimulation and oncogenic transformation: $85 \mathrm{kd}$ phosphoprotein and phosphatidylinositol kinase activity. Cell 50: 1021-1029, 1987.

7. Cantley LC, Whitman M, Chahwala S, Fleischman L, Kaplan DR, Schaffhausen BS and Roberts TM: Oncogenes and phosphatidylinositol turnover. Ann NY Acad Sci 488: 481-490, 1986.

8. Nishizuka Y: Discovery and prospect of protein kinase $\mathrm{C}$ research: epilogue. J Biochem 133: 155-158, 2003.

9. Kopp R, Noelke B, Sauter G, Schildberg FW, Paumgartner G and Pfeiffer A: Altered protein kinase C activity in biopsies of human colonic adenomas and carcinomas. Cancer Res 51: 205-210, 1991.

10. Levy MF, Pocsidio J , Guillem JG, Forde K, LoGerfo P and Weinstein IB: Decreased levels of protein kinase C enzyme activity and protein kinase C mRNA in primary colon tumors. Dis Colon Rectum 36: 913-921, 1993.

11. Kahl-Rainer P, Karner-Hanusch J, Weiss W and Marian B: Five of six protein kinase $\mathrm{C}$ iso-enzymes present in normal mucosa show reduced protein levels during tumor development in the human colon. Carcinogenesis 15: 779-782, 1994.

12. Ponta H, Sherman L and Herrlich PA: CD44: from adhesion molecules to signalling regulators. Nat Rev Mol Cell Biol 4: 33-45, 2003.

13. Ladeda V, Aquirre Ghiso JA and Bal de Kier Joffe E: Function and expression of CD44 during spreading, migration, and invasion of murine carcinoma cells. Exp Cell Res 242: 515-527, 1998.
14. Barshishat M, Ariel A, Cahalon L, Chowers Y, Lider O and Schwartz B: TNF $\alpha$ and IL-8 regulate the expression and function of CD44 variant proteins in human colon carcinoma cells. Clin Exp Metastasis 19: 327-337, 2002.

15. Fichter M, Hinrichs R, Eissner G, Scheffer B, Classen S and Ueffing M: Expression of CD44 isoforms in neuroblastoma cells is regulated by PI 3-kinase and protein kinase C. Oncogene 14: 2817-2824, 1997.

16. Barshishat M, Levi I, Benharroch D and Schwartz B: Butyrate down-regulates CD44 transcription and liver colonisation in a highly metastatic human colon carcinoma cell line. Br J Cancer 87: 1314-1320, 2002.

17. Zweibaum A, Pinto M, Chevalier G, Dussaulx E, Triadou N, Lacroix B, Haffen K, Brun JL and Rousset M: Enterocytic differentiation of a subpopulation of the human colon tumor cell line HT-29 selected for growth in sugar-free medium and its inhibition by glucose. J Cell Physiol 122: 21-29, 1985.

18. Hague A, Singh B and Pareskeva C: Butyrate acts as a survival factor for colonic epithelial cells: further fuel for the in vivo versus in vitro debate. Gastroenterology 112: 1036-1039, 1997.

19. Miller SJ: Cellular and physiological effects of short-chain fatty acids. Mini Rev Med Chem 4: 839-845, 2004

20. McIntyre A, Gibson PR and Young GP: Butyrate production from dietary fibre and protection against large bowel cancer in rat model. Gut 34: 386-391, 1993.

21. Lupton JR: Microbial degradation products influence colon cancer risk: the butyrate controversy. J Nutr 134: 479-482, 2004.

22. Lamerz R: Immunological comparison of carcinoembryonic antigen (CEA) extracted from tumors of various organs: their use in radioimmunological CEA determinations. Br J Cancer 47: 823-832, 1983 .

23. Kopp R and Pfeiffer A: Suramin alters phosphoinositide synthesis and inhibits growth factor receptor binding in HT-29 cells. Cancer Res 50: 6490-6496, 1990.

24. Assert R, Schatz H and Pfeiffer A: Upregulation of PKC delta and downregulation of PKC alpha-mRNA and protein by a phorbol ester in human T84 cells. FEBS Lett 388: 195-199, 1996.

25. van Weering DHJ, Baas PD and Bos JL: A PCR-based method for the analysis of human CD44 splice products. PCR Methods Appl 3: 100-106, 1993.

26. Matter N, Herrlich P and König H: Signal-dependent regulation of splicing via phosphorylation of SAM68. Nature 420: 691-695, 2002.

27. Cheng C and Sharp PA: Regulation of CD44 alternative splicing by Srm160 and its potential role in tumor cell invasion. Mol Cell Biol 26: 362-370, 2006.

28. Chen JS, Faller DV and Spanjaard RA: Short-chain fatty acid inhibitors of histone deacetylases: promising anticancer therapeutics? Curr Cancer Drug Targets 3: 219-236, 2003.

29. Germann A, Dihlmann S, Hergenhahn M, Doeberitz MK and Koesters R: Expression profiling of CC531 colon carcinoma cells reveals similar regulation of B-catenin target genes by both butyrate and aspirin. Int J Cancer 106: 187-197, 2003.

30. Taupin D and Podolsky DK: Mitogen-activated protein kinase activation regulates intestinal epithelial differentiation. Gastroenterology 116: 1072-1080, 1999.

31. Luongo D, Mazzarella G, Della RF, Maurano F and Rossi M: Down-regulation of ERK1 and ERK2 activity during differentiation of the intestinal cell line HT-29. Mol Cell Biochem 231: 43-50, 2002.

32. Lee JC, Maa MC, Yu HS, Wang JH, Yen CK, Wang ST, Chen YJ, Liu Y, Jin YT and Leu TH: Butyrate regulates the expression of c-Src and focal adhesion kinase and inhibits cell invasion of human colon cancer cells. Mol Carcinog 43: 207-214, 2005.

33. Cheng K and Raufman JP: Bile acid-induced proliferation of a human colon cancer cell line is mediated by transactivation of epidermal growth factor receptors. Biochem Pharmacol 70: 1035-1047, 2005.

34. Cheng K, Zimniak P and Raufman JP: Transactivation of the epidermal growth factor receptor mediates cholinergic agonistinduced proliferation of H508 human colon cancer cells. Cancer Res 63: 6744-6750, 2003.

35. Kopp R, Lambrecht G, Mutschler E, Moser U, Tacke R and Pfeiffer A: Human HT-29 colon carcinoma cells contain muscarinic $\mathrm{M}_{3}$ receptors coupled to phosphoinositide metabolism. Eur J Pharmacol 172: 397-405, 1989. 
36. Frucht H, Jensen RT, Dexter D, Yang WL and Xiao Y: Human colon cancer cell proliferation mediated by the M3 muscarinic cholinergic receptor. Biochim Biophys Acta 1588: 48-55, 2002.

37. Wang XQ, Yan Q, Sun P, Liu JW, Go L and McDaniel SM: Suppression of epidermal growth factor receptor signalling by protein kinase C-a activation requires CD82, caveolin-1 and ganglioside. Cancer Res 67: 9986-9995, 2007.

38. Nishizuka Y: Intracellular signalling by hydrolysis of phospholipids and protein kinase C. Science 258: 607-614, 1992.

39. Newton AC: Protein kinase C: structure, function and regulation. J Biol Chem 270: 28495-28498, 1995.

40. McMillan L, Butcher SK, Pongracz J and Lord JM: Opposing effects of butyrate and bile acids on apoptosis of human colon adenoma cells: differential activation of PKC and MAP kinases. Br J Cancer 88: 748-775, 2003.

41. Aihara H, Asaoka Y, Yoshida K and Nishizuka Y: Sustained activation of protein kinase $\mathrm{C}$ is essential to HL-60 cell differentiation to macrophages. Proc Nat Acad Sci USA 88: 11062-11066, 1991.

42. Assert R, Kötter R, Bisping G, Scheppach W, Stahlnecker W, Müller KM, Dusel G, Schatz H and Pfeiffer A: Anti-proliferative activity of protein kinase $\mathrm{C}$ in apical compartments of human colonic crypts: evidence for a less activated protein kinase $\mathrm{C}$ in small adenomas. Int J Cancer 80: 47-53, 1999.

43. Gokmen-Polar BY, Murray NR, Velasco MA, Gatalica Z and Fields AP: Elevated protein kinase $\mathrm{C}$ betaII is an early promotive event in colon carcinogenesis. Cancer Res 61: 1375-1381, 2001.

44. Suga K, Sugimoto I, Ito H and Hashimoto E: Down-regulation of protein kinase C-alpha detected in human colorectal cancer. Biochem Mol Biol Int 44: 523-528, 1998.

45. Orchel A, Dzierzewicz Z, Parfiniewicz B, Weglarz L and Wilczok T: Butyrate-induced differentiation of colon cancer cells is PKC and JNK dependent. Dig Dis Sci 50: 490-498, 2005.

46. Richard KL, Gibson PR, Young GP and PhillipsWA: Shortchain fatty acids reduce expression of specific protein kinase $\mathrm{C}$ isoforms in colonic epithelial cells. J Cell Physiol 182: 222-231, 2000.

47. Ragione FD, Criniti V, Della Pietra V, Borrello A, Oliva A, Indaco $S$, Yamamoto $T$ and Zappia V: Genes modulated by histone acetylation as new effectors of butyrate activity. FEBS Lett 499: 199-204, 2001.

48. Mulder JW, Krypt PM, Sewnath M, Oosting J, Seldenrijk CA, Weidema WF, Offerhaus GJ and Pals ST: Colorectal cancer prognosis and expression of exon-v6-containing CD44 proteins. Lancet 344: 1470-1472, 1994.

49. Wielenga VJ, van der Voort R, Mulder JW, Krypt PM, Weidema WF, Oosting J, Seldenrijk CA, van Krimpen C, Offerhaus GJ and Pals ST: CD44 splice variants as prognostic markers in colorectal cancer. Scand J Gastroenterol 33: 82-87, 1998.

50. Peng J, Lu JJ, Zhu J, Lu H, Lian P, Cai G and Cai S: Prediction of treatment outcome by CD44v6 after total mesorectal excision in locally advanced rectal cancer. Cancer J 14: 54-61, 2008.

51. Shtivelman E and Bishop MJ: Expression of CD44 is repressed in neuroblastoma cells. Mol Cell Biol 11: 5446-5453, 1991.

52. Zhang M, Wang M, Singh RK, Wells A and Siegal GP: Epidermal growth factor induces CD44 gene expression through a novel regulatory element in mouse fibroblasts. J Biol Chem 272: 24095-24101, 1997.
53. Bates RC, Edwards NS, Burns CF and Fisher DE: A CD44 survival pathway triggers chemoresistance via lyn kinase and phosphoinositide 3-kinase/Akt in colon carcinoma cells. Cancer Res 61: 5275-5283, 2001.

54. Harada N, Mizoi T, Kinouchi M, Hoshi K, Ishii S, Shiiba K, Saaki I and Matsuno S: Introduction of antisense CD44s cDNA down-regulates expression of overall isoforms and inhibits tumor growth and metastasis in highly metastatic colon carcinoma cells. Int J Cancer 91: 67-95, 2001.

55. Subramaniam V, Vincent IR, Gilakjan $M$ and Jothy S: Suppression of human colon cancer tumors in nude mice by siRNA CD44 gene therapy Exp Mol Pathol 83: 332-340, 2007.

56. Huang F, Hsu S, Yan Z, Winawer S and Friedman E: The capacity for growth stimulation by TGF beta 1 seen only in advanced colon cancers cannot be ascribed to mutations in APC, DCC, p53 or ras. Oncogene 9: 3701-3706, 1994.

57. Perletti G, Marras E, Osti D, Felici L, Zaro S and de Eguileor M: PKC delta requires p53 for suppression of the transformed phenotype in human colon cancer cells. J Cell Mol Med 8: 563-569, 2004.

58. Perletti G, Marras E, Dondi D, Osti D, Congiu T, Ferrarese R, de Eguileor $M$ and Tashjian AH Jr: p21(Waf1/Cip1) and p53 are downstream effectors of protein kinase $\mathrm{C}$ delta in tumor suppression and differentiation in human colon cancer cells. Int J Cancer 113: 42-53, 2005.

59. Yoshida K, Liu H and Miki Y: Protein kinase C delta regulates Ser46 phosphorylation of p53 tumor suppressor in the apoptotic response to DNA damage. J Biol Chem 281: 5734-5740, 2006.

60. Heerdt BG, Houston MA, Anthony GM and Augenlicht LH: Mitochondrial membrane potential (delta psi(mt)) in the coordination of p53-independent proliferation and apoptosis pathways in human colonic carcinoma cells. Cancer Res 58: 2869-2875, 1998.

61. Goldstein NS: Serrated pathway and APC (conventional)-type colorectal polyps: molecular-morphologic correlations, genetic pathways, and implications for classification. Am J Clin Pathol 125: 146-153, 2006

62. Gibson PR, Rosella O, Wilson AJ, Mariadason JM, Rickard K, Byron K and Barkla DH: Colonic epithelial cell activation and the paradoxical effect of butyrate. Carcinogenesis 20: 539-544, 1999.

63. Klampfer L, Huang J, Sasazuki T, Shirasawa S and Augenlicht L: Oncogenic Ras promotes butyrate-induced apoptosis through inhibition of gelsolin expression. J Biol Chem 279: 36680-36688, 2004.

64. Choudhary S and Wang HWR: Pro-apoptotic activity of oncogenic H-ras for histone deacetylase inhibitor to induce apoptosis of human colon cancer HT29 cells. J Cancer Res Clin Oncol 133: 725-739, 2007.

65. Cheng C, Yaffe MB and Sharp PA: A positive feedback loop couples ras activation and CD44 alternative splicing. Genes Dev 20: $1715-1720,2006$. 